
http://www.anpad.org.br/bar

BAR, Rio de Janeiro, v. 11, n. 2, art. 6, pp. 228-247, Apr./June 2014

\title{
Narratives and Sensemaking of an Organizationally-Based Environmental Disaster
}

\author{
Paulo Cesar Vaz Guimarães \\ E-mail address: pcvazguimaraes@gmail.com \\ FUNDACENTRO \\ Fundacentro, Rua Capote Valente, 05409002, Brasília, DF, Brazil. \\ Mário Aquino Alves \\ E-mail address: mario.alves@fgv.br \\ Fundação Getulio Vargas - EAESP/FGV
} EAESP/FGV, Av. Nove de Julho, 2029, $11^{\circ}$ andar, 01313-902, São Paulo, SP, Brazil.

Received $5^{\text {th }}$ February 2013; received in revised form $3^{\text {rd }}$ December 2013 (this paper has been with the authors for two revisions); accepted $4^{\text {th }}$ February 2014; published online $1^{\text {st }}$ April 2014. 


\begin{abstract}
This work investigates the narratives of corporations, public agencies, politicians, unions, lawyers, public attorneys and community in different public inquiries undertaken as a response to an organizationally-based environmental disaster in Brazil. In order to understand the phenomenon, this paper creates a framework that integrates sensemaking, narrative analysis and theater metaphor. Then we use the conceptual framework to analyze five public inquiries of an ongoing pollution caused by Shell's actions of producing, storing and dumping toxic chemical products in Vila Carioca, São Paulo, Brazil since the early 1940s. The analysis uncovers relationships between public management, corporations and society through their narratives, which are imbued with contradictions, revealing how meanings were selected, legitimized, codified and institutionalized.
\end{abstract}

Key words: narratives; disasters; sensemaking; theater metaphor. 


\section{Introduction}

Disasters derive from critical events that cause an urgent threat to the core functions of a social system and the consequences for individuals, society and environment are bad and irreversible (Freudenburg, 1997; Quarantelli, Lagadec, \& Boin, 2007).

There are naturally- or socially-caused disasters (Beamish, 2002; Gephart, 1984; Turner, 1978). Socially-based disasters develop through an incubation period and may be identified at their beginning. Socially-caused disasters generate more severe and long-lasting negative social, economic, cultural and psychological impacts than natural ones (Freudenburg, 1997). This is due to three main reasons: the indetermination of harm, the development of corrosive communities and sociocultural disruption (Hirschman, 1994). Disasters represent a type of event that pushes the limits. In more formal terms, they represent a focusing event, which amounts to an occurrence able to alter the formulation of one side's agenda and serve as a catalyst for mobilization, when groups seek to expand their sphere of influence (Birkland, 1998). The sensitivity associated with disasters stands out, in fact, in the communicative strategies between the actors, when, most of the time, mutual accusations prevail, aiming to find a culprit to punish, and setting out a sense of social justice. Accusation is not a deviation in gentlemanly conduct but a necessary social act for the maintenance of relations with others (Tilly, 2008), activating three logics: reconciliation, retaliation and reparation. However, a fourth possibility might be added: preserving the status quo with the continuity of normal life without social transformations (see Catino, 2008; Gephart, 1993).

An organizationally-based environmental disaster (OBED) is the type of socially-caused disasters that results from an organization's "exploitation of ecosystem resources and have potentially adverse effects on the ecosystem" and serial social effects (Gephart, 1984, p. 206). OBEDs are political phenomena (Gephart, 1984) that involve the power of corporations, governments, and society in the context where events take place.

Gephart, Van Maanen and Oberlechner (2009) present two organizational perspectives on risk that address the issue of accidents and disasters: the Normal Accident Theory (NAT) (Perrow, 1999) and the cognitive perspective of sensemaking (Weick, 1995, 2010). With NAT, Charles Perrow (1999) inserts the idea of problematic risk into organizational theory. He concludes there is a proliferation of plans where complex interactions between each unit of the production process predominate, with no possibility of foreseeing which one will take place and when. This state of things is helped along by the predominance of a high coupling between units, which accelerates the disruptive process and makes it difficult to intervene to come up with solutions. As Perrow (1999) links events to the social, political and economic context of organizations, his apparatus proves competent for describing organizational phenomenon from a macro scope. Weick $(1995,2010)$, with his perspective of sensemaking, opts to focus on the micro aspects of organizational life. In synthesis, actors in an organization seek to make sense of what they do through sensemaking, by interpreting and explaining the organization. The strongest efforts towards sensemaking are verified when the world is seen to be different from the expected, or when actors have difficulty discerning how to engage with the world (Weick \& Sutcliffe, 2006), like in disasters.

This work investigates the narratives of corporations, public agencies, politicians, unions, lawyers, public attorneys and community in different public inquiries undertaken as a response to an organizationally-based environmental disaster (Gephart, 1984) in Brazil. In order to understand the phenomenon, the paper creates a framework that integrates sensemaking (Gephart, 1984; Weick 1995, 2010), narrative analysis (Brown, Gabriel, \& Gherardi, 2009; Patriotta, 2003; Rhodes \& Brown, 2005), and theatrical metaphor (Czarniawska, 2006; Gioia \& Poole, 1984; Wood, 2002). Then, the conceptual framework is used to analyze five public inquiries of an ongoing pollution caused by Shell's actions of producing, storing and dumping toxic chemical products in Vila Carioca, São Paulo, Brazil since the 1940s. The analysis uncovers relationships between public management, corporations and society through their narratives, which are imbued with the contradictions, revealing how 
meanings were selected, legitimized, codified and institutionalized in a manner that resembles a theater play.

Combining sensemaking, narrative analysis and theatrical metaphor constitutes an theoretical contribution to the analysis of organizationally-based environmental disasters, since it generates a revelatory insight (Corley \& Gioia, 2011) of how social actors enact scripts that position themselves and other actors in the public realm.

In the introduction of this paper, we work with the definition of disasters and its relationship with communities and organizations. Next, there is a literature review on sensemaking and narratives, which provides the basis for our analysis. The third section presents the research design, showing how public documents can be used as sources for research in sensemaking, and how data analysis was conducted through the adoption of document-parsing code made up of different verbs that mark the phases of Turner's model (1976). The fourth section presents the case of the ongoing pollution in the areas occupied by Shell in the Vila Carioca and the reaction of political actors. Then, we present our findings, detailing the different roles enacted by the actors. In the last section, we discuss the results and highlight the findings.

\section{Sensemaking Approach to Disasters}

Weick (1995) describes seven properties which are intrinsic to sensemaking, which must be seen as a process: (a) based on the construction of identity; (b) retrospective; (c) acting within the environment; (d) of a social nature; (e) under construction; (f) characterized by evidence; and (g) directed by plausibility and not by accuracy. The retrospective characteristic of sensemaking is essential in order to allow that in their construction of self, people may find values and priorities, in the sense of guaranteeing themselves clarity about who they are and how to act. In other words, looking towards the past is not reduced to understanding what happened, but to clarify what happens now and what is the actor's role. As Weick (1995) points out, sensemaking removes the uncertainties about the time when events took place and produces a plausible story for the present. The proposition that the process of sensemaking should join with the actions taking place within the environment stems directly from the concept of enactment in the Weickean universe. Here, the word enactment is used in the sense of interaction between the actors in a process, in a chain that involves change, interaction, selection and retention.

The sensemaking process is social and political (Clark \& Geppert, 2011; Gephart, 1984, 1993). Its essence is the event, created through interaction with others. "Acts and speeches design non-linear cycles that build identity" (Weick, Sutcliffe, \& Obstfeld, 2005, p. 412). The characteristics of the cycle inform that the sensemaking process does not have a well-defined beginning or end and, when interrupted, incites reflection and can even incur a collapse of meaning (Weick, 1993). Disruptions in meaning are clearly disturbing, based on the perception that people become emotionally alert and need a new scenario to return to normality, especially due to new emerging complexities (Colville, Pye, \& Carter, 2013).

Escaping the rationalist tradition, in which a decision would be backed by precise and wellbased information, the sensemaking perspective understands that the organizational phenomenon is guided by clues that are plausible for the actors in scene. What is necessary is for these to continue being motivated to act, finding versions for their roles that depend on what they consider to be reasonable (Weick et al., 2005). However, "the construction of identity and the plausibility is the characteristic that distinguishes sensemaking in cognitive psychology" (Weick et al., 2005, p. 416). Between them, it is hard not to value the construction of identity, a dimension under great pressure in post-modernity. Sveningsson and Alvesson (2003) recognize the diffusion of research on how people and organizations structure selves and point to a certain recurrence of studies in which identity takes 
on static aspects. A more promising path lies in the emphasis of the dynamic aspects and in the endless struggles taking place throughout the meaning process (Bird, 2007).

Critical events, such as disasters, represent moments of sensemaking failure; which is only reestablished through official reports of post-crisis analyses (Boudes \& Laroche, 2009). Sensemaking properties help to understand the actions, activities and sensemaking processes that occurred within and between several organizations that operate in a disaster (Mills \& Weatherbee, 2006).

\section{Sensemaking, narratives and public inquiries}

Sensemaking is one of the more relevant among the fields that use narrative analysis, since stories can be accepted as a means for interpreting and bringing meaning to the events experienced (Rhodes \& Brown, 2005). For organizational studies, narratives make the interlacing of an organization's everyday characteristics viable and are a mechanism by which people reflect and talk about themselves, in the context of the organization, exposing existing perceptions. The advantage is in the minimization of the filters, helped along by the events taking place. Thus, narratives become imbued with the contradictions between people, revealing how meanings are selected, legitimized, codified and institutionalized by an organization (Patriotta, 2003).

Public document analysis, specifically, allows discursive practices to be approached as a multiplicity of sources for positioning at differentiated times (Gephart, 2007; Spink, 1999). Public documents are social products made public and, ethically, they are open for analysis as they belong to the public space, as they have been made public in a manner that permits liability. They can also reflect the slow transformations in institutional positions and postures that are assumed by the symbolic apparatus which permeates daily life (Spink, 1999). For Brown (2004) "an inquiry report renders visible what are often latent aspects of organizations, sheds light of how people make sense of complicated and problematic social situations, and how low probability, high-consequence events are dealt with" (p. 97). The content of public documents that refer to these inquiries, thus, "reflects rhetorical efforts designed to evoke attributions of verisimilitude on behalf of its target audience" (Brown, 2000, p. 45).

Dialectically, "public hearings and public inquiries can also promote platforms where the dominant discourse would be questioned and contested and new discourse could emerge" (Topal, 2009 , p. 280), thus launching the basis for organizational and institutional change. In truth, this potential stems from the fact that they are aimed at the analysis of crisis situations.

Gephart (2007) especially worries about the central role that sensemaking has in public hearings and inquiries which relate to crises, and also about these tools' functions in the crisis management process. Sensemaking tends to take place in situations where ambiguity and uncertainty are high (Weick, 2010). On the other hand, as Brown (2000) notes, these situations tend to be dealt with in a sense of reestablishing the myths placed at risk by the crises themselves, by constructing acceptable or relatively acceptable interpretations for events. Based on the premise that the comprehension of public inquiry reports constitutes a sensemaking exercise, Brown (2000) makes observations, which deserve to be considered here. For him, these reports: (a) objectify an allocation of responsibility and guilt; (b) function in order to reduce anxiety among technicians and society, generally by offering an explanation which promotes fantasies of comprehension and control; and (c) serve as a narrative model, a sensitizing archetype which supports understanding in similar events.

Elliott and McGuinness (2002) introduce confrontation among those who see public inquiries as a panacea, an opportunity to solve the problems associated with disasters, or as a placebo, creating the impression that remedies are being evaluated up to the moment when the incident under investigation leaves the public spotlight. In this view, relations of dominance would be present even within the judicial sphere, in seeking to push away the process of effective solutions that come into conflict with the status quo. 


\section{Method and Research Design, and Data Analysis}

A strongpoint of the sensemaking perspective is that it can be both a research method and an object of analysis in itself. In a heuristic sense, sensemaking provides a view of human action and its inter-relationships (for example, Mills \& Weatherbee, 2006; Mullen, Vladi, \& Mills, 2006; O'Connell $\&$ Mills, 2003); as a focus of preoccupation, the analyst chases the mechanisms which produce meaning (Blatt, Christianson, Sutcliffe, \& Rosenthal, 2006).

The initial priority in our research was the evaluation of the documentation gathered by municipal and state public hearings (CPIs), identifying any and all documents that mention the Vila Carioca case. An exception was made for the depositions, which were assumed to have been selected for later application of sensemaking. In sequence, this profusion of elements was read, selecting that which effectively adhered to the chosen case.

The next step consisted of gathering news from the media on the Vila Carioca contamination. For this purpose, we searched the sites of the Folha de São Paulo, Estado de São Paulo and Jornal da Tarde newspapers, and also consulted the House of Representatives search engine, since it maintains an updated and broad databank on newspaper and magazine news.

The empirical material collected makes the elements for scientific research fully available. Even when restricted only to the CPI records, the number of pages easily surpasses forty thousand. For this study, in order to apply the documental code, some ten-thousand pages were selected, with passages that mentioned the chosen case. The content has the great advantage of showing the communicative interaction between a wide variety of involved actors, who met at the Municipal Council. In virtue of the meeting space itself, it must be noted that there is a tendency for the participation of certain actors, especially political, to be overrated. Still, the CPIs (Public Hearings) documentation gathers the richest grouping of information about the case, keeping in mind sensemaking.

From the material found in the Municipal Council archives, the subsequent step was gathering the annual reports elaborated by Shell $(2003,2004,2005,2006,2007,2008)$ and by the organizations that traditionally confronted it, such as syndicates and non-governmental organizations (Friends of the Earth, 2003, 2004; Greenpeace, 2002; Observatório Social, 2003).

\section{Data analysis}

With the empirical material in hand, the next move was to elaborate a list of arguments which summarized both the phases of the Man-Made Disaster model by Turner (1976), aimed at analyzing organizational phenomena relating to crisis situations, and the elements he identified in his studies about accidents. With a view to contemplating efforts which came after the referred author, the list contained key topics which stemmed, mainly, from research by Gephart $(1984,1993,1997)$, Brown (2000, 2004), Mills and Weatherbee (2006), O'Connell and Mills (2003), Boudes and Larouche (2009) and Topal (2009), accompanied by the insights found in Weick $(1990,1993)$ relating to the construction of social actors' identities.

The list of arguments was subjected to a first effort to evaluate the concrete content of the final CPI reports, with the objective to discern which elements were appropriate for uncovering the narrative strategies for social actors' identity construction. Based on this initial effort, the next step was to adapt the group of topics and propositions worked with up until that moment into a code for documental analysis that would operationalize the sensemaking perspective. We made the decision to adopt verbs as key elements of the documental analysis code: prevenir (prevent), remediar (remediate), responsabilizar (hold responsible), naturalizar (naturalize), legitimar (legitimize) and restaurar (restore confidence), applied in the gerund form. The consideration was that these words have the potential to translate the significant positions of the actors - not necessarily the most frequent speeches (Weick, 1995), externalized in the process of public debates, and which reflect the 
communication strategies for sensemaking about self-identity. Verbs, as they are dynamic, translate the social action associated with narrative as discursive interaction in a more consistent manner and, thus, match the sensemaking perspective. In Portuguese in particular, the gerund form manages to capture sensemaking properties with greater precision.

By establishing that an action begins in the past and remains until the present, and that its significance is linked to the evolving role of an actor, this is the verb form which translates an action of an indefinite future, which constitutes the basis for elaborating the theatrical metaphor (Wood, 2002); in this case, the Shell drama at Vila Carioca. The theatrical metaphor provides a conceptual tool to investigate social actors' conduct in performing social roles, conceiving the social world as a staged play (Gioia \& Poole, 1984). It is assumed that the social actors in the social world act in many roles, so theatrical analysis allows us to see them as the roles they play in certain events (Czarniawska, 2006; Gioia \& Poole, 1984; Wood, 2002).

All actors' speech in the CPIs were then re-read one by one, in detail, evaluating the pertinence of the verbs identified above in actors' efforts to enact their scripts (Gioia \& Poole, 1984) along the evolution of events. These then were used to construct a data bank. With a basis in all excerpts of speech collected from the authors, according to the code of documental analysis and the readings carried out by the authors, the next section will present the possible scripts written by the actors and the roles they enacted.

\section{The Shell Scene at Vila Carioca}

Vila Carioca is a neighborhood in the city of São Paulo that includes the Ipiranga district (Ponciano, 2001). It is characterized by its geographical position as the primary path to the coastal Baixada Santista. Despite the fact that the area has been occupied since the city's foundation (Ponciano, 2001), its effective integration was brought about by the construction of the São Paulo Railway, later named the Estrada de Ferro Santos-Jundiaí (EFSJ), which opened to traffic in 1867. The ease of transportation brought by railway also explains Ipiranga's industrial prominence, which began in the beginning of the 20th century (Valentim, 2007). With regard specifically to Ipiranga, in the first decade of the twentieth century, due to the trend towards industrialization, workers were attracted by both the factories and by low land prices. Unlike neighborhoods like Brás, Bom Retiro and Mooca which had no potential for expansion, Ipiranga continued to arouse industry interest in the following decades. The inauguration of the Anchieta highway in 1947 further reinforced this vocation.

Despite the intensification of area development, in 1940 there were still many empty lots in the neighborhood at Vila Carioca conducive to industrial occupation. Shell was inaugurated in Vila Carioca in the 1940s, setting up a storage base for fuel and other chemical products on two lots of land close to the merging point of the Tamanduatei river with the Meninos brook, an area subject to constant flooding. There was no legislation at the time that demanded an environmental license for polluting enterprises, a study of environmental impact or any other sort of similar technical evaluation.

The first land lot, denominated BIP I, is around $180,000 \mathrm{~m}^{2}$ and was used from the start for fuel storage tanks. No one knows for how long, probably three decades, Shell buried oil sludge from tank cleaning directly in area soil, a common practice at the time. This generated "serious soil and water contamination which was not restricted to the lot of land" (Responsabilidades pela poluição sonora, 2006, p. 124).

The second lot, denominated BIP II, is around $24,000 \mathrm{~m}^{2}$. In the 40 's and 50 's, it was used as a service area for the pipelines that supplied the fuel storage base. After 1958, part of the site was used for producing organochloride and organophosphate pesticides by Shell Química, an activity which continued until 1978, when it was transferred to an industrial unit in Paulinia (SP). The remaining 
area, during this period, was used to "package petrochemical products acquired in bulk, store canned products, produce industrial detergents and stock lubricants" (Valentim, 2007, pp. 118-119).

Besides BIP I and BIP II, there is an area named Colorado, of around 40,000m², used until 1972 by Shell for employee sporting and leisure activities and, later, for an administrative unit, which was shut down in 1997.

The first accusations of contamination problems with the area occupied by Shell in Vila Carioca emerged in 1993, through the environmental organization Greenpeace Brazil and the Syndicate of Workers in the Commerce of Minerals Derived from Petroleum in the State of São Paulo (Sinpetrol), who sent representatives to the State Public Attorney (public prosecutors office - MP) on their behalf. Technical evaluation by the Institute of Technological Research of the State of São Paulo (IPT) detected the presence of lead in the soil. In the same year, sludge from oil derivatives was found to have been buried at the location by the company. The MP set up a civil inquiry to investigate the case. The investigations commenced after 1993 indicated contaminants such as BTX (benzene, toluene and xylene) and heavy metals, especially lead, buried in different spots in the area occupied by the company in Vila Carioca.

In 2002, the MP opened a public civil lawsuit against Shell and Cetesb due to the environmental problems identified at the location (Responsabilidades pela poluição sonora, 2006). In the same year, Greenpeace Brazil included Shell and the specific case of the Vila Carioca contamination among its Corporative Environmental Crimes in Brazil (Greenpeace, 2002).

The debates among environmentalists on contamination in Vila Carioca had a significant repercussion and reached an international dimension with the inclusion, by the Friends of the Earth organization, of detailed considerations about the case in reports on environmental problems relating to Shell's activities throughout the world. The summary presented in the reports states:

For decades the residents of Vila Carioca in Sao Paulo, Brazil, have been using drinking water contaminated by the nearby joint Shell ExxonMobil facility. In 1993 local unions joined Coletivo Alternativa Verde (Green Alternative Collective) and Greenpeace, and filed a complaint in the courts, citing contamination of Vila Carioca with hydrocarbons, heavy metals, and organochlorides. Since then, despite investigations by local health and environmental authorities, progress, if any, has been slow. Despite evidence which indicates breaches of environmental law, Shell has yet to be prosecuted. (Friends of the Earth, 2003, p. 22).

People living near the Shell facilities in Vila Carioca and Paulinia in Sao Paulo can recount numerous incidents when Shell dumped and buried toxic pesticides and oil wastes. Investigations led by the Sao Paulo government in 2002 revealed that the land and water in the region, including drinking water wells, were contaminated with lead, cadmium, and other heavy metals, as well as several toxic chemicals, including benzene, toluene, and the pesticides DDT and aldrin. In addition, medical tests proved that workers at the facility were contaminated with the types of toxins associated with Shell's operations. (Friends of the Earth, 2004, p. 10).

Oliveira (2005) states that, between 1993 and 2003, Shell was fined once by the municipal government for infractions in the area, for operating without a license, and four times by the state environmental organ, in this case Cetesb, for water contamination and delays in reporting water and soil conditions, but the company appealed in both instances.

The Vila Carioca contamination was noted even at the federal Legislative level. In 2002, the Commission for the Defense of Consumers, Environment and Minorities of the Chamber of Representatives held a public hearing specifically aimed at debating soil and water contamination by chemical products in the neighborhood (A contaminação da Vila Carioca, 2002).

In the Municipal Council of São Paulo, contamination in the area occupied by Shell in the neighborhood was investigated by a sequence of four parliamentary hearing commissions (CPIs), as follows: the CPI to investigate responsibility for irregularities in the construction of gas stations - CPI 
dos Postos de Combustíveis (Irregularidades em postos de combustíveis, 2002); the CPI to investigate responsibility for environmental contamination and liabilities - CPI do Passivo Ambiental (Responsabilidades por contaminação e passivo ambiental, 2003); the CPI to investigate responsibility for sound, atmospheric, water, soil and subsoil pollution, besides the environmental liabilities - CPI da Poluição (Responsabilidades pela poluição sonora, 2006); and the CPI to investigate responsibility for environmental damage and its respective liabilities, due to the exercise of inadequate, irregular or illegal industrial and economic activities and practices - CPI dos Danos Ambientais (Danos ambientais e seus respectivos passivos, 2010).

The first of these commissions, the CPI dos Combustiveis, verified that the contamination in the area occupied by Shell was not restricted to contamination by oil derivatives, but organochlorides were also present. Also, Cetesb did not alert local inhabitants to the risk of contamination, which caused the deep well, serving four hundred families in the Auriverde community, to distribute water contaminated by dieldrin and tetrachloethene. After carrying out exams, the CPI dos Combustíveis found at least 28 cases of contamination by chemical agents and heavy metals (Responsabilidades pela poluição sonora, 2006).

The CPI do Passivo Ambiental verified an important fact: since the inhabitants of Vila Carioca were not serviced by a public water supply system until the 1970's, they used domestic wells for a long time. They continued to use these wells even during the 1980's due to cuts in the implemented supply system (Responsabilidades por contaminação e passivo ambiental, 2003).

The investigations were halted for a while, and then taken up by the CPI da Poluição. In relation to negative impact on the local inhabitants, the final CPI da Poluição report called attention to over six-thousand people exposed to risks in the area and stated:

Shell Brazil has proceeded, through reprehensible conduct, to bury highly pollutant, toxic and carcinogenic products, during an undetermined period of time, resulting in the contamination of soil/subsoil/surface and underground waters. By means of its contaminants it has invaded others' properties, violating the private life of inhabitants, making it difficult for them to exercise their citizenship rights, altering the area's and its inhabitants' images, setting obstacles to their right to their properties, causing them illness and health problems and preventing their residences from fulfilling the social function guaranteed by law. (Responsabilidades pela poluição sonora, 2006, p. 140)

The same report brings relevant data from different technical reports relating to contamination in Vila Carioca. Among several other points, it explains that the municipal Coordination of Health Vigilance (Covisa) verified contamination problems in the soil, water and air. Within the findings relating to the issue, the mortality rate in Vila Carioca was verified to be very high (Responsabilidades pela poluição sonora, 2006).

The list of health problems potentially generated by the contaminants found in Vila Carioca is frightening. Aldrin, dieldrin and DDT (dichlorodiphenyltrichloroethane) are considered carcinogenic and mutagenic. Benzene causes alterations in bone marrow and can generate leukemia, among other problems. Several of the identified contaminants can lead to death (Responsabilidades pela poluição sonora, 2006).

The CPI da Poluição final report (Responsabilidades pela poluição sonora, 2006) highlights that, in BIP I, despite the long period of time which passed between the first accusations, the delimitation of the contaminated area had not yet been concluded. Also, the remediation work in the area contaminated by Shell remained almost at a standstill between 2003 and 2006. In fact, primary and secondary sources of contamination remained in all the areas, bringing serious risks to the population.

In 2009, the CPI dos Danos Ambientais once again analyzed contamination in Vila Carioca, among several other cases of environmental degradation within the city of São Paulo. The final report contains information that shows that the effects of contamination in the area are far from receiving a 
final solution. According to estimates presented by the municipal health department, out of the 28,072 current inhabitants of Vila Carioca, 6,538 are exposed to the contamination caused by Shell do Brasil, but the necessary specific toxicological exams have not yet been carried out. The patients of Vila Carioca are considered and treated in the public health system to not be contaminated, but chronically ill. The local population complains it is not included in decision-making processes, and has also suffered real estate devaluation because of environmental liabilities (Danos ambientais e seus respectivos passivos, 2010).

Between 2002 and 2003, the state and municipal environmental departments, together with Shell representatives and the local population, held a series of meetings that produced a Term of Conduct Adjustment (TAC) to assure that "the company would carry out or pay for the necessary actions of evaluation and environmental remediation" (Valentim, 2007, p. 138). The definitive formalization of this TAC, however, was unsuccessful. One of the reasons the TAC did not work out might be the negative reaction of the population.

In this manner, Shell has been treating the community with absolute disdain and the Term of Conduct Adjustment would be absolutely convenient for this company, which wishes to remove itself from the penalties that Cetesb may confer. In fact, this Term of Adjustment provide opportune defense for Shell in the records of the case against it by the Public Attorney, which questions the attitude of both defendants (Shell/Cetesb) (Irregularidades em postos de combustíveis, 2002, p. 10752).

In 2004, the Federal Prosecutors Office in São Paulo filed criminal procedures against Shell, for causing pollution with direct health damage to the population, and against the Agência Nacional do Petróleo (ANP), for the non-compliance with legal obligations of observing and monitoring, as well as against two employees of the BBL S/C Ltda. enterprise, hired by ANP, for inserting false declarations in their report and altering judicially relevant facts.

Both the previously mentioned public civil suit opened by the State Justice Department and the criminal suit by the Federal Justice Department are still ongoing. The large number of possible appeals, along with other rules regarding lawsuits in the country, has certainly not helped the case.

The Public Attorney of Labor (MPT) has also been investigating the issue, in regards to contamination within the company and its effects on the workers' health. This initiative resulted in the production, in 2004, of a specific TAC on employee health, in which Shell agreed to adopt measures such as soil and underground water monitoring and remediation of the internal area of the Vila Carioca terminal.

\section{The Analysis of the Vila Carioca Drama}

From the application of the theater metaphor to a sensemaking based on narratives, the analysis that follows reveals the different scripts that social actors enacted in the staging of Vila Carioca drama.

\section{Municipal legislature}

Politicians seek to strengthen their original role: representatives elected by the population. For this, the scenic resources are varied, from pantomime, when they use a grandiloquent style of discourse, already satirized by popular culture, to the authoritarian posture, taking on the power of the empire as an integral part of the State.

We have found in São Paulo environmental skeletons which frighten us by their proportion, due to the time they have been active and the lack of responsibility of those who caused them, for 
we cannot call a company responsible that takes forty, fifty years, half a century, to make public, by self-denouncement, the contamination of immense areas. (Irregularidades em postos de combustíveis, 2002, p. 381).

This speech in its entirety is an exercise in placing blame. In this passage, the politician externalizes vigorous criticism directed specifically at Shell. It is worth explaining, however, that the investigations about contamination in Vila Carioca were started in 1993 by data sent to the Public Attorney by the environmental organization Greenpeace Brazil and by Sinpetrol. It is as if the accusations by civil society had no implications, with the incubation phase remaining valid and not the phases of precipitation and shock.

The standard character played by the politician is the voice of the population, independent of party affiliation. It must be pointed out that a delegate gains a more symbolic that substantial personification, as it is self-endowed, also remembering that representatives seldom invited the represented constituents to the CPIs. This character does not alter throughout the events, even when the inefficiency of his participation is obvious.

President, in another CPI which involved the Shell discussion, we had positive results and I would like for the largest beneficiary of this process to participate in this CPI, which is the population and which did not participate. With the exception of the case, for example, my criticism is that in Vila Carioca they set a date for blood tests etc. Up to now the population does not know what happened to those exams, no one was informed of absolutely anything. This means we have begun to treat the population as a sub-product of this case of ours, no one knows anything (Responsabilidades pela poluição sonora, 2006, p. 31).

In that episode, example, of the semi-tubular deep well, of the Condominio Auriverde, which had drins [a chemical family including Aldrin, Endrin, Isodrin, etc.], with poison, insecticides, we closed it off, the CPI closed it off and explained this to the population. However, we still don't have the results because the governmental organs make access to information difficult, thus the importance of this CPI (Responsabilidades pela poluição sonora, 2006, p. 37).

The politician externalizes the preoccupation with the lack of information passed on to the local inhabitants, placing the responsibility for this on the governmental entities, testifying that in 2006, thirteen years after precipitation of the accident, the adjustment phase remained in effect. The editing by the CPIs itself on the theme, although the titles reflect subtle changes in the political agenda, is a sign that the script was not being altered by the intervention of the Legislature. Also press coverage, which is vital for broadening public debate, did not take hold and ran out of breath after the play began. The most serious sign of inefficiency, however, is in the results from the Legislature: during almost ten years, the only existing law was only very recently edited and its scope is secondary.

\section{Environmental agency}

Cetesb incorporates a typical character of its time of creation (the 1970's): the prevalence of technical rationality, with the reification of science. This characteristic ends up shaping a character that is impermeable in regards to the outside world, with a mechanism where the administrator/administrated interaction, which is itself asymmetrical in terms of power, reaches a highly hermetic situation. With this, an organization which would need to aim at attaining the status of highly reliability cannot deal with a situation that, in the vision of NAT, should be almost trivial, of low complexity and loosely linked. "This information came later, [the existence of drins]. So was discovered that they were fined, at the time, because we found there were drins buried in the region of Colorado street. Cited and fined" (Irregularidades em postos de combustíveis, 2002, p. 11.691).

So, this risk report [from 2000] is practically invalidated because it establishes conditions for risk analysis for a previous situation of which we now have data whose situation has changed, including data that contamination was detected in the Colorado street area, outside the Shell area. (Irregularidades em postos de combustíveis, 2002, p. 11.753). 
well, but we have superficial knowledge, and no one can understand, in the Shell case, how the contamination took that route towards the Vila Carioca neighborhood.... With the dissemination of contamination news, in the press, we found out that others were consuming the water. So, this is why we started to investigate outside Shell's area. (Irregularidades em postos de combustíveis, 2002, pp. 11.767-11.768).

The reference to a lack of technical knowledge on the soil contamination theme at the time of the first accusations, or even to the unknown flow that contaminated the Auriverde community, is adopted by the environmental agency to refute questions about their actions which imply coresponsibility for at least part of the problems. With the technical knowhow, however, the necessary measures were then taken. This may be the biggest example that the belief in previous knowledge serves for the future. Grounding itself upon its scientific repertory, Cetesb never considered the hypothesis, already signaled in 1999, that the contamination would change its supposedly natural course and reach the Auriverde. Throughout the entire story, here we find the main symbol in Weick's universe, when the technician faces a situation which confronts all his presuppositions. Apparently, however, a collapse of sensemaking did not take place, with the organization finding new technical discourses to preserve its identity.

The faith in its technical base is so dogmatic that it appears to reach the frontiers of organizational autism, once a former position, proclaimed as certain, is contested by subsequent facts, without causing changes in character. In other words, no collapse of sensemaking takes place, mostly because of the naturalization of events. The entire sequence of episodes with contrasting content is sewn together with a conductor thread, which transmits the idea that what happened is what should have happened and that the trust in the organization, responsible for environmental quality, is not sub judice.

Various statements demystify the organization's unity in terms of values. There are clearly conflicting streams and, at certain moments, it seems as though the character reflects about the way his work unfolds and begins a learning process in the sense of changing practices and values.

The damage is contained in a report which was filed by the Health Department both here in the CPI da Poluição as with Cetesb and this result, together with the risk analysis that Cetesb is preparing aims to show that some people who had a compound of a DDT derivative in their blood, that would be DDE, which is a substance which was found present. It may, however, bear no relation exclusively with the Shell site ... In relation to the drins, specifically, the fact that the substance was present in the bloodstream does not indicate, necessarily, a symptom of disease (Responsabilidades pela poluição sonora, 2006, p. 3.745).

There is an inflection here in the environmental agency discourse, besides it being in conflict with the regional health office's position. The Cetesb representative states that the contamination verified in some of the local inhabitants may not be exclusively related with Shell's activities. It is not too difficult to remember that only Shell produced the product associated with the contamination. The technical rigor sets the basis for the environmental agency's position in the sense of excluding part of Shell's responsibility and exposes the change in the organization's positioning. Up to this point, it is certain that Cetesb has always turned to technical knowledge, which did not stop it from pressuring the company and seeking to take care of the population.

\section{Shell}

This character maintains coherence throughout the events. Its intention is to transmit permanent cooperation with the other characters, compatible with the proposition of corporative social responsibility. In the actual conflicts, however, one can note the recurring strategy of procrastination, making use of technical and juridical justifications. When the conflict is exacerbated by external blaming, the company's reaction acquires harsher tones and the arguments lose sophistication. At the limit, such as when the population is held responsible for contamination due to pesticide use, or when 
judicial actions are brought about in order to impede the population from undergoing toxicological exams, all of the company's masks come off.

[In answer to the question of the possible origin of the benzopyrene detected in residences] Either way it is important, if it really originates from fuel burning, to make it clear that Vila Carioca, the area in the Ipiranga region, is a greatly industrialized area, where in reality the industrialization still often uses fuel burning to generate vapor and heat, in other words, boilers are used in most of the industries.... the benzopyrene could come from the burning of fuels and which would be associated to the social characteristic of Vila Carioca. (Responsabilidades por contaminação e passivo ambiental, 2003, p. 3.737).

It is true that, in the case of benzopyrene, which has known carcinogenic properties, the connections with Shell's activities are not as simple as with the compounds related to pesticides that only the company handled in the area. Anyway, the preoccupation of Shell's representative in diluting the responsibility with the other polluting enterprises in the area is clear. Here, the actor calls for accuracy of evidence, not accepting mere plausibility.

Another discursive strategy is to always attempt to share responsibility with public agents for the solution of problems, giving out the impression that the initiatives taken can be considered a partnership with the public powers and not the result of a legal imposition. This strategy appeared in full during the TAC debate, when the measures proposed by the company fell far behind those required by the public civil suit, leading to a failure in negotiations. It should be noted that the existence of a space for agreement was favorable to the company, which used it as a justification for not assuming the responsibility for immediate intervention directed at the population. As the event has persisted for over a decade, the inference that use of decoys was the rule in the lawsuits is not made lightly.

there is a disseminated presence of drins in the region, but always below the intervention values of Cetesb, showing in some way that (sic) drins were used by the population in the past, probably for agriculture, ants, other types of uses. (Responsabilidades por contaminação e passivo ambiental, 2003, p. 3.767).

This small passage is the height of the drama and does not allow passive acceptance. The mask of the company falls and the population is held responsible for the drins found in the contaminated area, because it used ant poison.

\section{Health protection agency}

The health protection agency starts out in the play almost as a secondary actor and rises to primary actor when it elaborates a character with solid postures. Although sharing the same original sin as the state environmental organ, which is in having technical knowledge as its only anchor, from the moment in which it managed to structure an argument which was consistent for itself - the causal link between the company's activities and the population's health conditions - it maintained coherence with its creed.

Then, we took the period 1993 to 2004 - sometime around there, I can't recall exactly, but it is a ten year period -, and the following was observed: that the mortality rate in Vila Carioca is higher than the rest of the Ipiranga district. There, more people die.... This report, in truth, we delivered to the Public Attorney, which was agreed on at a hearing at the Public Attorney, and the Public Attorney, later, was to promote a meeting between the involved parts and lead future proceedings. This did not take place.... Councilors, I would like to underline an aspect, which is important to clear up. The link between exposure and contamination is epidemiological and has been established by the Covisa and health coordination team. (Responsabilidades pela poluição sonora, 2006, pp. 6.866-6.867 and 6.883). 
The position of the State health protection agency remains constant in this sense: there is a link between Shell activity, the exposure of the local population and the detected health problems.

\section{Municipal government}

The municipal government of São Paulo is perhaps the character with less awareness of its strength. Although wielding robust public policy tools for the management of urban space, its appearance in the scene is of a hapless being, with each constitutive part striving to choose its own path. When it appears as a whole, it opts for a conciliatory discourse, assuming the posture of a mediator, but letting show the old come-and-go function.

From the start we have accompanied this matter, due to its serious nature, for involving an area where the sub-prefecture has concerns about territorial development. We have followed [the unfolding of events] and been receptive, we have contact with SOS Vila Carioca. We have tried to thus serve as an intermediary so that things may happen. (Responsabilidades pela poluição sonora, 2006, p. 6.851).

The municipal government's representative seeks to consolidate legitimacy in an intermediary position between the different actors involved. It seems that the local government, in truth, undervalued its own role, since it has important prerogatives in its hands, including the temporary or definitive interdiction of activities.

\section{Municipal environmental agency}

Because from the moment in which the law created our Department it linked all institutional arrangements and rearrangements to the existence of an Environmental Code [which has not yet reached the Council] ... when this Code did not exist ..., each Department continued to work the same way, in other words, who was doing things, carried on doing things, who was not doing things continued [to not do things]. (Irregularidades em postos de combustíveis, 2002, p. 717).

The municipal sphere of government seems in principle too unorganized to manage the environmental theme, which probably strengthens the weight of Cetesb's role in the case at hand. The department's representative sets out these deficiencies without a qualm, demonstrating that deviations become natural.

This is an actor that, while still young in this drama, seems to opt for being an Ionescan rhinoceros (from Eugene Ionescan, Theatre of the Absurd playwright), not the beast that motivates debate, but that which undergoes metamorphosis. The speeches are disconnected and it is hard to understand which role it wants to play. When it attempts to move to the center, it manages to destabilize communication among the other characters in an indelible manner, with the ill-fated TAC. Due to its lack of presence, perhaps the quiet of the shadows was preferable. "Now a group of people arrives, and comes up to the population, and says: you are sick because of Shell. I am going to file a lawsuit, and you, sirs, will be compensated" (Responsabilidades pela poluição sonora, 2006, p. 4.689).

I repeat, the mistake was to go to the population and alert them that the population was sick, had been contaminated by Shell and that by means of a lawsuit the population will have financial compensation for these damages, and that the TAC was standing in the way of compensation. (Responsabilidades pela poluição sonora, 2006, p. 4.718).

The representative of the municipal department of the environment, in fact, was laying the responsibility for the problems at the feet of the community leaders. Without going into the merit of the accusation itself, the problem with the contamination was that the population became aware of it? The speech reveals the disregard for external opinions and the contempt for the dangers, a phenomena identified by Turner (1976). It also reveals the identity that the municipal government constructs, as a secondary character, which wants to remain in the background. 


\section{Unions}

The character that acted as catalyst for the drama soon leaves the scene, whether through its own choice or through contingencies, returning only at the end. It must be recognized that its role remained active backstage, reaching international forums and broadcasting the contamination problems. Independent of whether the spectator or other actors like its speech, the character is coherent with its aims to question the status quo.

So, we could start a very serious discussion in relation to this because Cetesb, who is the monitoring and regulating organ of this whole environmental issue, they are, I don't know up to what point, complicit with these great oil transnationals ... what did Shell do at its Vila Carioca terminal? Washed out tanks, ... took the toxic waste with tetraethyl lead, heavy metals and buried it ... Shell has no responsibility in its own terminal (Irregularidades em postos de combustíveis, 2002, pp. 495-496).

The Sinpetrol, as previously mentioned, led the first accusations about the contamination in 1993. After nine years without a solution to the problem, the aggressive tone would be expected even as a matter of political coherence.

\section{State legislative}

The state representatives took their time in deciding if they would like to take part in the play and which role they would take on. Discussion in the CPI on fuel adulteration was fleeting and the attempt to start another discussion specifically about contamination was unsuccessful for years. The 2010 CPI had the result of providing impulse for the approval of the state law on contaminated areas, a relevant event. The elaboration of this law, however, raises concerns, since it was created quickly and the population had little chance to voice their opinions. About Vila Carioca, specifically, the only thing requested in state commissions was the material that Cetesb and the Public Attorney possessed, without the statements of those directly affected. Apparently, the state Legislature was taking part in another play on a neighboring stage.

\section{Community association}

Without a question the most cited character in the play, the local population, had little direct voice in the statements. When they had the opportunity, they structured a proud character clamoring for its rights. What calls our attention is that, of all characters, this is the one that improves its discourse, adding sophisticated arguments gathered during the debates with the other organizations to the accusations. It is the only one, actually, that demands urban re-qualification, attempting to embrace the problem as a whole.

The inhabitants are in the same position. Shell is working on soil remediation around the company grounds. I ask: and us, the community? ... We, through the judiciary powers ... have attempted to set up a meeting with Secretary Eduardo Jorge and he has never answered us.... Sirs [Councilors], in a meeting in 2003 a company representative told us that we, local inhabitants, could have contaminated the environment with BHC, which was often used to kill rats at the time, and neocid, which was often used by housewives to kill fleas and cockroaches. Even that, we heard.... The company alleges that there are many contaminating enterprises, which may have contaminated the soil.... Except that only Shell produced the organochloride derivatives, this must be made clear. (Responsabilidades pela poluição sonora, 2006, pp. 6.8866.889).

The reasoning the community representative has for allocating responsibility is clear: in the strange attempt to blame the community for the contamination by supposedly having used an excessive amount of ant-killing poison, Shell forgets that it produced the pesticide itself. In terms of civil responsibility, that excuse would not save Shell from reparations for verified damage. 
The reduced efficacy reflects the political-institutional apparatus which does not absorb popular opinion. Even so, at great cost, they managed to push for a number of measures and, until the CPI faded away in 2009, they had maintained their demands and their anger with the way both the public administration and the State acted.

\section{Public attorney}

This is a character that acts behind the scenes and does not often take the stage. However, this does not stop it from constant participation: since the original 1993 denunciation it has been present and continues so until the present moment, accompanying the lawsuits it has filed. It is true that at the start its involvement was timid, so much so that the lack of action resulting from the clash between Cetesb and Shell only resulted in rigid intervention in 2001. What calls our attention, and is rare in the other characters, is the capacity for understanding its role and its limit, which does not mean it is satisfied.

Currently, we have a public civil lawsuit which has been running for four years, with a number of requests, both in the environmental sphere as in public health, both for the employees and the neighbors. The preliminary injunctions requested in this suit, of preliminary investigations into the population's health, the soil, listing of people who have presented any sickness related to the use of organochlorides have been denied, both in first and second instance, both in the State and Federal Justice. They have been repeatedly reiterated. With each new fact that emerges, the request is reiterated, but until now, justice has not given a single step.... So, as the State will not arm itself, we will always be chasing our losses, always attempting a preliminary injunction which is never conceded, always trying to keep the population from invading contaminated land. (Responsabilidades pela poluição sonora, 2006, pp. 6.994-7.001).

The Public Attorney statement maintains a vigorous position placing both Shell and Cetesb against the wall. Shell must repair the damage caused to the population because the causal link has been established. Cetesb was negligent and should also answer for this, according to law. Intermediary decisions in the lawsuit, however, have gone against the Public Attorney's demands. What has taken place, in the end, is that almost fifteen years of mutual accusations have not reached either reparation or reconciliation; retaliation, one may say, has been confined to the judicial branch. Reproduction of the past has become the key issue, with all its deleterious consequences for those without a voice.

\section{Final Remarks}

This work investigates the sensemaking undertaken by the actors involved in an organizationally based environmental disaster, seeking, by analyzing the narratives, elements which could characterize the characters in a drama. The subjacent idea was to evaluate if the predominance of blaming and denial, a typical and perhaps necessary strategy in these situations, could lead to communication which would evolve in preserving the fabric of society. Karl Weick's sensemaking approach was partly used due to its explicative flexibility and strength and, mainly, for allowing a non-dogmatic gaze at the construction of identity that the actors undergo in order to make sense of their social role. This approach provokes us with their stories, making available kaleidoscopes that, at each move, produce a different picture, with unexpected collages which sharpen perception and make us question what we knew as certain. The operational aspect of the model, in accordance with the sensemaking perspective, was made using analysis of documents from the CPIs and other sources. The methodology used the construction of a documental code able to classify the actors' speeches and thus gather material that presented narrative evolution of the greatest number of involved parties in the selected case. Thus, through the utilization of the theater metaphor, the characters would have to take on behaviors that would be modified as the drama unfolded, elaborating new acts, which, as long as they did not alter the primordial identity, could raise the curtains for possibilities of new encounters. 
The Vila Carioca contamination case study provided an example of crisis situation which, despite being in theory not difficult to deal with - the definition of the origin of contamination did not seem in principle to be complex, the polluter is a company which has sought to appear environmentally and socially responsible, and there were basic rules to guide the actions of the public powers - continued for years without a final solution, a situation which is still ongoing at the present time. Since 1993, when the public administration was first contacted by the community and called the company to task, a communication process began in which the accusation did not manage to forge paths, whether by reparation, reconciliation or retaliation, for preserving the social ties. Certainly, even though Vila Carioca did not witness an anomic rupture, its current reality is no reason to celebrate.

What stands out is that the Shell site should not have brought such immeasurable complications, to the point of not yet being resolved. After all, the operation at these installations is of low complexity and loosely linked, the responsibility of a company which up to the 1980's was held as a reference in strategic planning, and which had incorporated environmentalist discourse (Livesey, 2001). All these aspects counted towards selection of this case, but the main issue, for the authors, is that this is a problem of continuous pollution, a phenomenon rarely studied by the social sciences, with the exception, for example, of the remarkable work by Beamish (2002). Understanding the stories told by the actors is a duty of academia, bearing in mind that the number of people who may be affected by this silent evil is much higher than those involved in explosive events, and that, usually, those who live in the outskirts or other areas occupied by the low-income population are excluded. Up to the edition of this article, the impact on the population is unknown and the liabilities have been diluted. This work demonstrated how this non-answer to the problem was enacted by the organizations based on the identity they built in the social scenario.

\section{References}

A contaminação da Vila Carioca: audiência perante a Comissão de Defesa do Consumidor, Meio Ambiente e Minorias, Câmara dos Deputados, 51d Cong.,1 (2002).

Beamish, T. (2002). Silent spill. Cambridge: The MIT Press.

Bird, S. (2007). Sensemaking and identity: the interconnection of storytelling and networking in a women's group of a large corporation. Journal of Business Communication, 44(4), 311-339. doi: $10.1177 / 0021943607306135$

Birkland, T. (1998). Focusing events, mobilization, and agenda setting. Journal of Public Policy, 18(1), 53-74.

Blatt, R., Christianson, M., Sutcliffe, K., \& Rosenthal, M. (2006). A sensemaking lens on reliability. Journal of Organizational Behaviour, 27(7), 897-917. doi: 10.1002/job.392

Boudes, T., \& Laroche, H. (2009). Taking of the heat: narrative sensemaking in post-crisis inquiry reports. Organization Studies, 30(4), 377-396. doi: 10.1177/0170840608101141

Brown, A. (2000). Making sense of inquiry sensemaking. Journal of Management Studies, 37(1), 4575. doi: 10.1111/1467-6486.00172

Brown, A. D. (2004). Authoritative sensemaking in a public inquiry report. Organization Studies, 25(1), 95-112. doi: 10.1177/0170840604038182

Brown, A. D., Gabriel, Y., \& Gherardi, S. (2009). Storytelling and change: an unfolding story. Organization, 16(3), 323-333. doi: 10.1177/1350508409102298 
Catino, M. (2008). A review of literature: individual blame vs. organizational function logics in accident analysis. Journal of Contingencies and Crisis Management, 16(1), 53-62. doi: 10.1111/j.1468-5973.2008.00533.x

Clark, E., \& Geppert, M. (2011). Subsidiary integration as identity construction and institution building: a political sensemaking approach. Journal of Management Studies, 48(2), 395416. doi: 10.1111/j.1467-6486.2010.00963.x

Colville, I., Pye, A., \& Carter, M. (2013). Organizing to counter terrorism: Sensemaking amidst dynamic complexity. Human Relations, 66(9), 1201-1223. doi: 10.1177/0018726712468912

Corley, K. G., \& Gioia, D. A. (2011). Building theory about theory building: what constitutes a theoretical contribution?. Academy of Management Review, 36(1), 12-32.

Czarniawska, B. (2006). A golden braid: Allport, Goffman, Weick. Organization Studies, 27(11), 1661-1674. doi: 10.1177/0170840606068344

Danos ambientais e seus respectivos passivos, decorrentes do exercício de atividades e práticas industriais e econômicas inadequadas, irregulares ou ilegais: audiência perante a Comissão Parlamentar de Inquérito dos Danos Ambientais, Câmara Municipal de São Paulo, 15d Cong., 1 (2010).

Elliott, D., \& McGuinness, M. (2002). Public inquiry: panacea or placebo? Journal of Contingencies and Crisis Management, 10(1), 14-25. doi: 10.1111/1468-5973.00177

Freudenburg, W. R. (1997). Contamination, corrosion and the social order: an overview. Current Sociology, 45(3), 19-39. doi: 10.1177/001139297045003002

Friends of the Earth. (2003). Behind the shine: the other Shell Report 2003. Retrieved from http://www.foe.co.uk/sites/default/files/downloads/behind_shine.pdf

Friends of the Earth. (2004). Lessons not learned: the other Shell Report 2004. Retrieved from http://www.foe.ie/download/pdf/shell_lessons_not_learned_2004.pdf

Gephart, R. (1984). Making sense of organizationally based environmental disasters. Journal of Management, 10(2), 205-225. doi: 10.1177/014920638401000205

Gephart, R. P., Jr. (1993). The textual approach: risk and blame in disaster sensemaking. The Academy of Management Journal, 36(6), 1465-1514. doi: 10.2307/256819

Gephart, R. P., Jr. (1997). Hazardous measures: an interpretive textual analysis of quantitative sensemaking during crises. Journal of Organizational Behavior, 18(S1), 583-622. doi: 10.1002/(SICI)1099-1379(199711)18:1+<583::AID-JOB908>3.0.CO;2-T

Gephart, R. P., Jr. (2007). Crisis sensemaking and the public inquiry. In C. Pearson, C. Roux-Dufort, \& J. Clair (Eds.), International handbook of organizational crisis management (pp. 123-160). Thousand Oaks: Sage Publications.

Gephart, R. P., Jr., Van Maanen, J., \& Oberlechner, T. (2009). Organizations and risk in late modernity. Organization Studies, 30(2/3), 141-155. doi: 10.1177/0170840608101474

Gioia, D. A., \& Poole, P. P. (1984). Scripts in organizational behavior. Academy of Management Review, 9(3), 449-459. doi: 10.5465/AMR.1984.4279675

Greenpeace. (2002). Crimes ambientais corporativos no Brasil. Retrieved from http://www.greenpeace.org.br/toxicos/pdf/corporate_crimes_port.pdf 
Hirschman, A. (1994). Social conflicts as pillars of democratic market society. Political Theory, 22(2), 203-218. doi: 10.1177/0090591794022002001

Irregularidades em postos de combustíveis: audiência perante a Comissão Parlamentar de Inquérito dos Postos de Combustíveis, Câmara Municipal de São Paulo, 13d Cong.,1 (2002).

Livesey, S. M. (2001). Eco-identity as discursive struggle: Royal Dutch/Shell, Brent Spar, and Nigeria. Journal of Business Communication, 38(1), 58-91. doi: 10.1177/002194360103800105

Mills, J. H., \& Weatherbee, T. G. (2006). Hurricanes hardly happen: sensemaking as a framework for understanding organizational disasters. Culture and Organization, 12(3), 265-279. doi: $10.1080 / 14759550600871485$

Mullen, J., Vladi, N., \& Mills, A. (2006). Making sense of the Walkerton crisis. Culture and Organization, 12(3), 207-220. doi: 10.1080/14759550600865933

Observatório Social. (2003). Comportamento social e trabalhista: mapa da empresa. Retrieved from http://www.observatoriosocial.org.br/portal/sites/default/files/biblioteca/rel_mapa_shell_mai20 03.pdf

O'Connell, C. J., \& Mills, A. J. (2003). Making sense of bad news: the media, sensemaking, and organizational crisis. Canadian Journal of Communication, 28(3), 323-339.

Oliveira, J. (2005). Shell's environmental responsibility in Vila Carioca, São Paulo, Brazil (Unpublished manuscript). University of Notre Dame, Notre Dame, EUA.

Patriotta, G. (2003). Sensemaking on the shop floor: narratives of knowledge in organizations. Journal of Management Studies, 40(2), 349-375. doi: 10.1111/1467-6486.00343

Perrow, C. (1999). Normal accidents: living with high-risk technologies. New Jersey: Princeton University Press.

Ponciano, L. (2001). Bairros paulistanos de A a Z (2a ed.). São Paulo: Editora Senac.

Quarantelli, E. L., Lagadec, P., \& Boin, A. (2007). A heuristic approach to future disasters and crises: new, old and in-between types. In R. Dynes, H. Quarantelli, \& H. Rodriguez (Eds.), Handbook of disaster research (pp. 16-41). New York: Springer.

Responsabilidades pela poluição sonora, atmosférica, da água, do solo e do subsolo, além dos passivos ambientais: audiência perante a Comissão Parlamentar de Inquérito da Poluição, Câmara Municipal de São Paulo, 14d Cong.,1 (2006).

Responsabilidades por contaminação e passivo ambiental: audiência perante a Comissão Parlamentar de Inquérito do Passivo Ambiental, Câmara Municipal de São Paulo, 13d Cong.,1 (2003).

Rhodes, C., \& Brown, A. D. (2005). Narrative, organizations and research. International Journal of Management Reviews, 7(3), 167-188. doi: 10.1111/j.1468-2370.2005.00112.x

Shell. (2003). Relatório de sustentabilidade da Shell no Brasil [Relatório não publicado], Rio de Janeiro, Brasil, Shell.

Shell. (2004). Relatório de sustentabilidade da Shell no Brasil [Relatório não publicado], Rio de Janeiro, Brasil, Shell.

Shell. (2005). Relatório de sustentabilidade da Shell no Brasil [Relatório não publicado], Rio de Janeiro, Brasil, Shell. 
Shell. (2006). Relatório de sustentabilidade da Shell no Brasil [Relatório não publicado], Rio de Janeiro, Brasil, Shell.

Shell. (2007). Relatório de sustentabilidade da Shell no Brasil [Relatório não publicado], Rio de Janeiro, Brasil, Shell.

Shell. (2008). Relatório de sustentabilidade da Shell no Brasil [Relatório não publicado], Rio de Janeiro, Brasil, Shell.

Spink, P. (1999). Análise de documentos de domínio público. In M. Spink, Práticas discursivas e produção de sentidos no cotidiano (pp. 123-151). São Paulo: Cortez.

Sveningsson, S., \& Alvesson, M. (2003). Managing managerial identities: organizational fragmentation, discourse and identity struggle. Human Relations, 56(10), 1163-1193. doi: $10.1177 / 00187267035610001$

Tilly, C. (2008). Credit and blame. New Jersey: Princeton University Press.

Topal, C. (2009). The construction of general public interest: risk, legitimacy, and power in a public hearing. Organization Studies, 30(2/3), 277-300. doi: 10.1177/0170840608101481

Turner, B. A. (1976). The organizational and interorganizational development of disasters. Administrative Science Quarterly, 21(3), 378-397.

Turner, B. A. (1978). Man made disasters. London: Wykeham Publications.

Valentim, L. (2007). Requalificação urbana, contaminação do solo e riscos à saúde: um caso na cidade de São Paulo. São Paulo: Annablume/Fapesp.

Weick, K. E. (1990). The vulnerable system: an analysis of the Tenerife air disaster. Journal of Management, 16(3), 571-593. doi: 10.1177/014920639001600304

Weick, K. E. (1993). The collapse of sensemaking in organizations: the Mann gulch disaster. Administrative Science Quarterly, 38(4), 628-652.

Weick, K. E. (1995). Sensemaking in organizations. Thousand Oaks: SAGE Publications.

Weick, K. E. (2010). Reflections on enacted sensemaking in the bhopal disaster. Journal of Management Studies, 47(3), 537-550. doi: 10.1111/j.1467-6486.2010.00900.x

Weick, K. E., \& Sutcliffe, K. M. (2006). Mindfulness and the quality of organizational attention. Organization Science, 17(4), 514-524. doi: 10.1287/orsc.1060.0196

Weick, K. E., Sutcliffe, K. M., \& Obstfeld, D. (2005). Organizing and the process of sensemaking. Organization Science, 16(4), 409-421. doi: 10.1287/orsc.1050.0133

Wood, T., Jr. (2002). Spectacular metaphors: from theatre to cinema. Journal of Organizational Change Management, 15(1), 11-20. doi: 10.1108/09534810210417348 